doi: https://doi.org/10.15407/dopovidi2019.05.091

УДК 582.736.3

\title{
С.М. Романчук
}

Інститут ботаніки ім. М.Г. Холодного НАН України, Київ

E-mail: rrsm@ukr.net

\section{Вплив X-опромінення на експресію гена $\beta$-глюкозидази PYK 10 в проростках Arabidopsis thaliana (L.) Heynh.}

Представлено членом-кореспондентом НАН України Є.Л. Кордюм

Вперше досліджено експресію гена $\beta$-глюкозидази РYК 10 в проростках $A$. thatiana під дією $X$-опромінення 8 дозах 0,5, 1, 2, 4, 6, 8, 10 та 12 Гр. Встановлено, що за умов $X$-опромінення збільшення кількості ЕР-тілещь та підвищення активності $\beta$-глюкозидази відбувається за рахунок високої експресії гена РҮК 10. Вперше показано роль ЕР-тілещь, які містять $\beta$-глюкозидазу (РYК 10), в адаптащї проростків $A$. thalianа на дію $X$-опромінення. Підвищення експресї гена РYК 10 за цих умов є частиною внутрішньої програми захисту на вплив зовнішніх чинників.

Ключові слова: ген РYК 10, $\beta$-глюкозидаза, ЕР-тільия, X-опромінення, Arabidopsis thaliana.

На сьогодні поглиблюються дослідження щодо механізмів адаптації рослин до мікрогравітації та іонізуючої радіації, оскільки рослини є головним компонентом автотрофної ланки біорегенеративних систем життєзабезпечення космонавтів [1]. Згідно з даними НАСА (США) на орбітальній станції в межах кабіни космічного корабля дози іонізуючої радіації, які впливають на живі організми, коливаються в діапазоні від 5 до 12 мкГр/год [2]. Серед видів рослин, які використовувалися в космічних і наземних експериментах, найбільш стійкими до радіаційного випромінювання вважаються представники родини Brassicaceae, для яких описані ЕР-тільця (рис. 1), що є похідними гранулярного ендоплазматичного ретикулума (ЕР).

EР-тільця в клітинах Arabidopsis thaliana [3] вибірково накопичують фермент $\beta$-глюкозидазу (глюкозидглюкогідролазу, КФ 3.2.1.21 (PYК10)) [4] із сигналом утримання в компартментах ЕР [5]. У попередніх дослідженнях нами встановлено, що ЕР-тільця є чутливими до кліностатування (симульованої мікрогравітації) та дії Х-опромінення, оскільки відбувалося збільшення кількості та площі ЕР-тілець на зрізах статоцитів і клітин дистальної зони розтягу (ДЗР) кореневих апексів A. thaliana у середньому в два рази відносно контролю $[6,7]$. Також нами виявлено збільшення активності $\beta$-глюкозидази під дією Х-опромінення порівняно з контролем [8]. Підвищення або зниження рівня експресії під впливом чинників космічного польоту відомо для великого числа генів, залучених у широке коло

(C) С.М. Романчук, 2019 


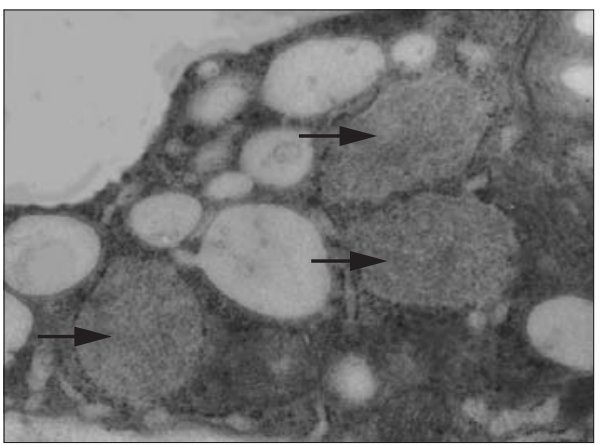

Puc. 1. Фрагмент клітини дистальної зони розтягу кореневого апекса A. thaliana. Стрілками вказані ЕР-тільця (трансмісійна електронна мікроскопія). Масштаб - 200 нм

клітинних процесів, у тому числі $\mathrm{Ca}^{2+}$ і ліпід-сигналінг, біосинтез клітинної оболонки, загальний метаболізм, насамперед вуглеводний і ліпідний, реакції на стрес, синтез білків [9, 10]. Основними моделями у цих експериментах слугували проростки A. thaliana. У наших дослідженнях з моделювання мікрогравітації встановлено, що за умов кліностатування у проростках A. thaliana відбувається значне підвищення відносної експресії гена PYK 10 порівняно зі стаціонарними умовами росту [11]. Вивчення впливу X-опромінення на експресію гена $\beta$-глюкозидази $P Y K 10$ у проростках A. thaliana доповнить розуміння ролі ЕР-тілець в адаптації рослин до зовнішніх чинників.

Для досліджень використовували проростки Arabidopsis thaliana (L.) Heynh., екотип Columbia (Col-0), вирощені з попередньо стерилізованого та стратифікованого насіння, яке висівали на живильне середовище Мурасіге та Скуга у чашки Петрі діаметром 120 мм по 100-120 насінин у кожну. Проростки росли за умов освітлення 93 мкмоль $\cdot \mathrm{M}^{-2} \cdot \mathrm{c}^{-1}$ із фотоперіодом 16/8 год (світло/темрява) при температурі $22-24{ }^{\circ} \mathrm{C}$ та вологості $67 \pm 1 \%$ протягом 3 та 13 діб з моменту проростання насіння. 3-добові проростки, що росли в окремих чашках Петрі, опромінювали рентгенівськими променями на приладі РУМ-17 (Росія) (потужність дози 0,43 сГр/с) у дозах 0,5, 1, 2, 4, 6, 8, 10 та 12 Гр. У експерименті брали проростки через 2 год та 10 діб після Х-опромінення. Контролем слугували 3- та 13-добові проростки, які не були опромінені.

Для виділення РНК брали по 100 мг проростків відразу після закінчення експериментів. Операцію проводили з використанням набору реактивів TRI-REAGENT (“Sigma”, Німеччина) за інструкцією, наданою виробником реактивів. Для контролю якості РНК відразу після iii виділення проводили електрофорез в 1\%-му агарозному гелі в трис-ацетатному буфері (TAE). Перед синтезом кДНК для видалення слідів геномної ДНК виділену РНК обробляли ДНКазою I (“Fermentas”, Литва). кДНК отримували з РНК за допомогою реакції зворотної транскрипції з використанням набору реактивів “Fermentas” зі зворотною транскриптазою M-MLV (“Fermentas”, Литва) за інструкцією, наданою виробником реактивів, на приладі “Терцик” (“ДНК-Технология”, Росія). ПЛР у реальному часі проводили з використанням набору реактивів “Maxima Sybr Green Real Time” (“Fermentas”, Литва) за інструкцією, наданою виробником реактивів, на приладі “Real-Time PCR IQ-Cycler” (“BioRad”, США). Для визначення відносної експресії гена $\beta$-глюкозидази A. thaliana PYK 10 (At3g09260) вибрано праймери з бази даних NCBI (http://www.ncbi.nlm.nih.gov):

прямий: 5'-AGGATTGTGAAGGATTTCCGAGA-3';

зворотний: 5'-AGAAGAGCAACGACCAGGTG-3'.

Кінцева концентрація праймерів у готовому розчині становила 5 пМ; реакційний об’єм - 20 мкл. Інтенсивність флуоресценції вимірювали при температурі 77-79 ${ }^{\circ} \mathrm{C}$, криву плавлення - у діапазоні $60-94{ }^{\circ} \mathrm{C}$ з інтервалом $0,5{ }^{\circ} \mathrm{C}$. Час вимірювання становив 10 с. 
Одержані результати аналізували за допомогою програмного забезпечення приладу. Рівень відносної експресії гена $P Y K 10$ виражали в умовних одиницях (у. о.).

Усі дослідження проводили не менше ніж у трьох біологічних та трьох аналітичних повторах. Статистичну обробку даних здійснювали за критерієм Стьюдента ( $T$-test) $(p \leqslant 5 \%)$ та з використанням дисперсійного аналізу (ANOVA). Побудову діаграми виконано в програмі Excel пакета Microsoft Office 2010.

Отримані результати ПЛР у реальному часі показали значне зростання щодо контролю відносної експресії гена $P Y K ~ 10$ у 3-добових проростках через 2 год після дії кожної дози $\mathrm{X}$-опромінення (рис. 2). Найбільші значення відносної експресї гена $P Y K ~ 10$ спостерігали за умов впливу $\mathrm{X}$-опромінення в дозах 0,5 та 8 Гр, яка була вищою порівняно з контролем у 5,4 та 5,5 раза відповідно. Х-опромінення у дозах 2 та 12 Гр спричиняло підвищення відносної експресії гена $P Y K 10$ у 4,7 раза, 1 та 6 Гр - у 4,6 раза, 10 Гр - у 4,5 раза, 4 Гр - у 4,4 раза щодо контролю.

Через 10 діб після Х-опромінення у 13-добових проростках також встановлено значне зростання відносної експресї гена РYК 10 під дією кожної дози порівняно з контролем (див. рис. 2). Найбільші значення відносної експресії гена $P Y K 10$ також відмічали у разі дії доз 0,5 та 8 Гр, яка була вищою від контролю у 6,6 та 6,2 раза відповідно. Х-опромінення в дозі 12 Гр спричиняло зростання відносної експресії гена $P Y K 10$ у 5,3 раза, 10 Гр - у 4,9 раза, 1 Гр - у 4,5 раза, 2 та 4 Гр - у 4,2 раза, 6 Гр - у 4,1 раза порівняно 3 контролем.

Варто відзначити, що відносна експресія гена $P Y K 10$ через 2 год після X-опромінення була значно вищою за таку через 10 діб після X-опромінення (див. рис. 2), а саме: у разі

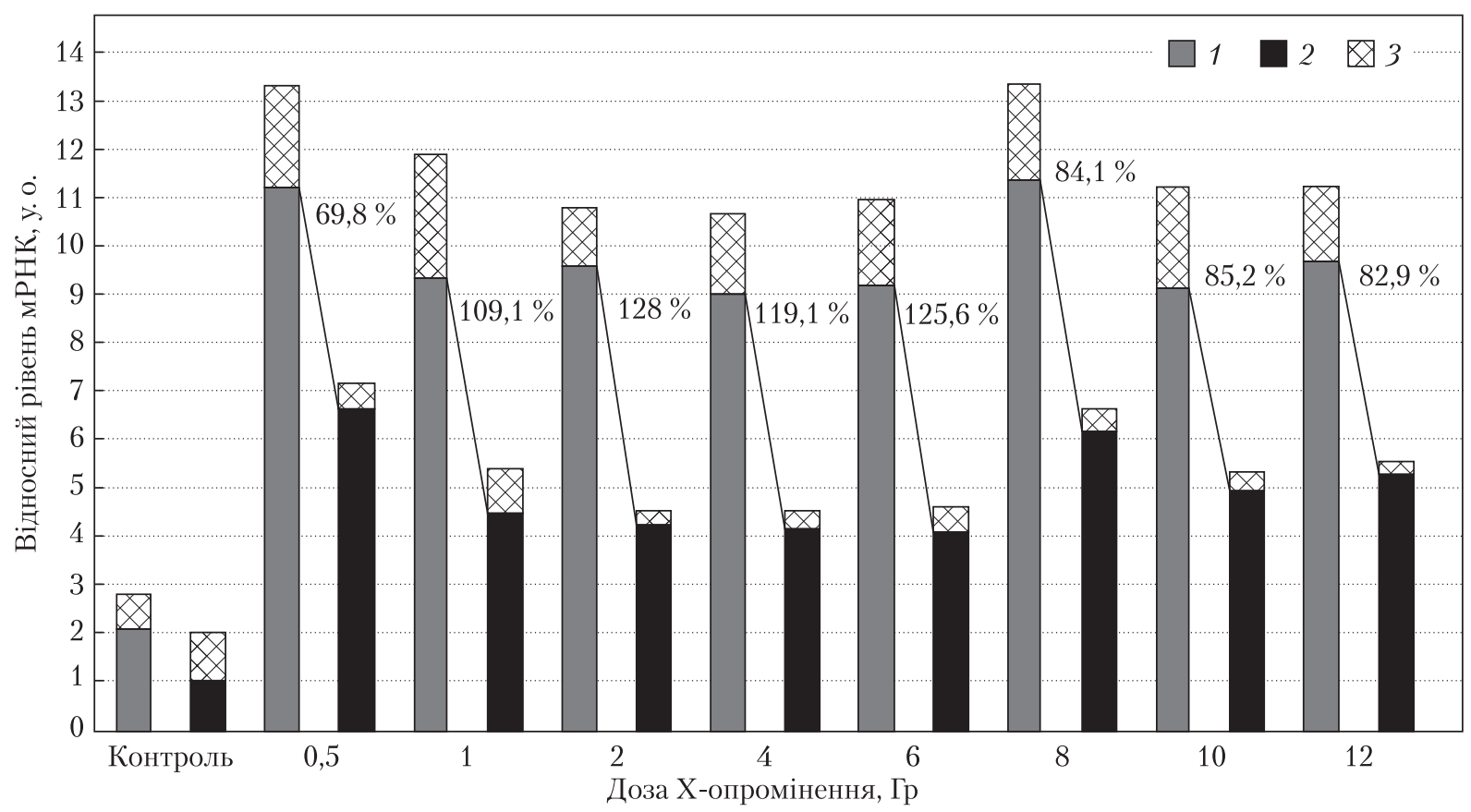

Puc. 2. Відносна експресія гена $\beta$-глюкозидази $P Y K ~ 10$ в контролі, через 2 год та через 10 діб після Х-опромінення 3-добових проростків A. thaliana в різних дозах. 1 - 3-добові проростки; 2 - 13-добові проростки, 3 - стандартне відхилення 
опромінення в 0,5 Гр - на 69,8 \%; 1 Гр - на 109,1\%; 2 Гр - на 128 \%; 4 Гр - на 116,1 \%; 6 Гр на 125,6 \%; 8 Гр - на 84,1 \%;10 Гр - на 85,2 \%; 12 Гр - на 82,9 \%.

Вперше отримані нами результати щодо підвищення відносної експресії гена $\beta$-глюкозидази PYK 10 у проростках A. thaliana за умов X-опромінення в дозах 0,5, 1, 2, 4, 6, 8, 10 та 12 Гр по відношенню до контролю узгоджуються з результатами, отриманими під час дослідження ультраструктури ЕР-тілець, головним компонентом яких є $\beta$-глюкозидаза. Виявлено, що їхня кількість та площа на зрізах статоцитів і клітин ДЗР кореневих апексів $A$. thaliana також збільшувалася після Х-опромінення порівняно з контролем більш ніж удвічі [7]. Також ці результати узгоджуються з даними визначення активності $\beta$-глюкозидази через 2 год та 10 діб після Х-опромінення в дозах від 0,5 до 12 Гр [8]. Таким чином, результати ПЛР у реальному часі засвідчили, що за умов Х-опромінення збільшення кількості ЕР-тілець та підвищення активності $\beta$-глюкозидази відбувається за рахунок високої експресії гена $P Y K 10$. Також нами встановлено, що як експресія гена $P Y K$ 10, так і активність $\beta$-глюкозидази через 10 діб після X-опромінення були меншими порівняно з такими через 2 год після X-опромінення. Цей факт може свідчити про те, що за період 10 діб захисні реакції клітин A. thaliana на дію іонізуючої радіації набувають адаптивного характеру, ключову роль в яких виконує $\beta$-глюкозидаза. Результати багатьох експериментів інших дослідників також показали, що під дією на проростки A. thaliana зовнішніх чинників, таких як механічне пошкодження поверхневих тканин рослини $[12,13]$, дія гормонів $[12,14]$, колонізація коренів рослини ендофітними грибами [15], зростала експресія гена $\beta$-глюкозидази $P Y K 10$ порівняно 3 контролем. Отримані нами результати повною мірою підтверджують літературні відомості щодо накопичення мРНК $\beta$-глюкозидази (PYK 10) в проростках A. thaliana під дією зовнішніх чинників.

\section{ЦИТОВАНА ЛІТЕРАТУРА}

1. Sychev V.N., Levinskikh M.A., Podolsky I.G. Biological component of life support systems for a crew in longduration space expeditions. Acta Astronaut. 2008. 63. P. 1119-1125. doi: https://doi.org/10.1016/j. actaastro.2008.01.001

2. International Space Station Internal Radiation Monitoring (ISS Internal Radiation Monitoring) - 05.04.2017. URL: https://www.nasa.gov/mission_pages/station/research/experiments/1043.html

3. Hayashi Y., Yamada K., Shimada T., Matsushima R., Nishizawa N.K., Nishimura M., Hara-Nishimura I. A proteinase-storing body that prepares for cell death or stresses in the epidermal cells of Arabidopsis. Plant Cell Physiol. 2001. 42. P. 894-899. doi: https://doi.org/10.1093/pcp/pce144

4. Ketudat Cairns J.R., Esen A. B-glucosidases. Cell Mol. Life Sci. 2010. 67, № 20. P. 3389-3405. doi: https:// doi.org/10.1007/s00018-010-0399-2

5. Matsushima R., Kondo M., Nishimura M., Hara-Nishimura I. A novel ER-derived compartment, the ER body, selectively accumulates a $\beta$-glucosidase with an ER retention signal in Arabidopsis. Plant J. 2003. 33. P. 493502. doi: https://doi.org/10.1046/j.1365- 313X.2003.01636.x

6. Romanchuk S.M. Ultrastructure of the statocytes and cells of the distal elongation zone of Arabidopsis thaliana under the conditions of clinorotation. Cytol. Genet. 2010. 44, № 6. P. 329-333. doi: https://doi. org/10.3103/S0095452710060010

7. Romanchuk S. ER bodies in Arabidopsis thaliana root apices under clinorotation and after X-Ray irradiation. Plant functioning under environmental stress: Proceedings of the 9th International conference (Cracow, Poland, 12-15 Sept. 2012). Cracow, 2012. P. 185-192.

8. Романчук C.M. Активність $\beta$-глюкозидази в проростках Arabidopsis thaliana (L.) Heynh при дії іонізуючого випромінювання. Вісн. Харків. нащ. ун-ту ім. В. Н. Каразіна. Сер. Біологія. 2017. Вип. 29. С. 103-108. doi: https://doi.org/10.26565/2075-5457-2017-29-13 
9. Paul A.-L., Zupanska A., Ostrow D.T., Zhang Y., Sun Y., Li J.-L., Shanker S., Farmerie W.G., Amalfitano C.E., Ferl R.J. Spaceflight transcriptomes: Unique responses to a novel environment. Astrobiology. 2012. 12. P. 4056. doi: https://doi.org/10.1089/ast.2011.0696

10. Correll M.J., Pyle T.P., Millar K.D.L., Sun Y., Yao J., Edelmann R.E., Kiss J.Z. Transcriptome analyses of Arabidopsis thaliana seedlings grown in space: implications for gravity-responsive genes. Planta. 2013. 238. P. 519-533. doi: https://doi.org/10.1007/s00425-013-1909-x

11. Romanchuk S.N., Kordyum E.L. ER bodies in Arabidopsis thaliana seedlings are sensitive to simulated microgravity and ionizing radiation. ELGRA Newsletter. 2014. 9. P. 10-11.

12. Matsushima R., Hayashi Y., Kondo M., Shimada T., Nishimura M., Hara-Nishimura I. An endoplasmic reticulum derived structure that is induced under stress conditions in Arabidopsis. Plant Physiol. 2002. 130. P. 1807-1814. doi: https://doi.org/10.1104/pp.009464

13. Ogasawara K., Yamada K., Christeller J.T., Kondo M., Hatsugai N., Hara-Nishimura I., Nishimura M. Constitutive and inducible ER bodies of Arabidopsis thaliana accumulate distinct $\beta$-glucosidases. Plant Cell Physiol. 2009. 50, № 3. P. 480-488. doi: https://doi.org/10.1093/pcp/pcp007

14. Matsushima R., Fukao Y., Nishimura M., Hara-Nishimura I. NAI1 gene that encodes a basic-helix-loop-helixtype putative transcription factor that regulates the formation of a novel ER-derived structure, the ER body. Plant Cell. 2004. 16. P. 1536-1549. doi: https://doi.org/10.1105/tpc.021154

15. Sherameti I., Venus Y., Drzewiecki C., Tripathi S., Dan V.M., Nitz I., Varma A., Grundler F.M., Oelmüller R. PYK10, a $\beta$-glucosidase located in the endoplasmatic reticulum, is crucial for the beneficial interaction between Arabidopsis thaliana and the endophytic fungus Piriformospora indica. Plant.J. 2008. 54. P. 428-439. doi: https://doi.org/10.1111/j.1365-313X.2008.03424.x

Надійшло до редакції 28.02.2019

\section{REFERENCES}

1. Sychev, V. N., Levinskikh, M. A. \& Podolsky, I. G. (2008). Biological component of life support systems for a crew in long-duration space expeditions. Acta Astronaut, 63, pp. 1119-1125. doi: https://doi.org/10.1016/j. actaastro.2008.01.001

2. International Space Station Internal Radiation Monitoring (ISS Internal Radiation Monitoring) - 05.04.2017. Retrieved from https://www.nasa.gov/mission_pages/station/research/experiments/1043.html

3. Hayashi, Y., Yamada, K., Shimada, T., Matsushima, R., Nishizawa, N. K., Nishimura, M. \& Hara-Nishimura, I. (2001). A proteinase-storing body that prepares for cell death or stresses in the epidermal cells of Arabidopsis. Plant Cell Physiol., 42, pp. 894-899. doi: https://doi.org/10.1093/pcp/pce144

4. Ketudat Cairns, J. R. \& Esen, A. (2010). ß-glucosidases. Cell Mol. Life Sci., 67, No. 20, pp. 3389-3405. https://doi.org/10.1007/s00018-010-0399-2

5. Matsushima, R., Kondo, M., Nishimura, M. \& Hara-Nishimura, I. (2003). A novel ER-derived compartment, the ER body, selectively accumulates a $\beta$-glucosidase with an ER retention signal in Arabidopsis. Plant J., 33, pp. 493-502. doi: https://doi.org/10.1046/j.1365- 313X.2003.01636.x

6. Romanchuk, S. M. (2010). Ultrastructure of the statocytes and cells of the distal elongation zone of Arabidopsis thaliana under the conditions of clinorotation. Cytol. Genet., 44, No. 6, pp. 329-333. doi: https://doi. org/10.3103/S0095452710060010

7. Romanchuk, S. (2012, September). ER bodies in Arabidopsis thaliana root apices under clinorotation and after X-Ray irradiation. Proceedings of the 9th International Conference Plant functioning under environmental stress (pp. 185-192). Cracow.

8. Romanchuk, S. M. (2017). The $\beta$-glucosidase activity in Arabidopsis thaliana (L.) Heynh seedlings under exposure to ionizing radiation. J. V.N. Karazin Kharkiv National University, Iss. 29, pp. 103-108. doi: https:// doi.org/10.26565/2075-5457-2017-29-13

9. Paul, A.-L., Zupanska, A., Ostrow, D. T., Zhang, Y., Sun, Y., Li, J.-L., Shanker, S. Farmerie, W. G., Amalfitano, C. E. \& Ferl, R. J. (2012). Spaceflight transcriptomes: Unique responses to a novel environment. Astrobiology, 12, pp. 40-56. doi: https://doi.org/10.1089/ast.2011.0696

10. Correll, M. J., Pyle, T. P., Millar, K. D. L., Sun, Y., Yao, J., Edelmann, R. E. \& Kiss, J. Z. (2013). Transcriptome analyses of Arabidopsis thaliana seedlings grown in space: implications for gravity-responsive genes. Planta, 238, pp. 519-533. doi: https://doi.org/10.1007/s00425-013-1909-х 
11. Romanchuk, S. N. \& Kordyum, E. L. (2014). ER bodies in Arabidopsis thaliana seedlings are sensitive to simulated microgravity and ionizing radiation. ELGRA Newsletter, 9, pp. 10-11.

12. Matsushima, R., Hayashi, Y., Kondo, M., Shimada, T., Nishimura, M. \& Hara-Nishimura, I. (2002). An endoplasmic reticulum derived structure that is induced under stress conditions in Arabidopsis. Plant Physiol., 130, pp. 1807-1814. doi: https://doi.org/10.1104/pp.009464

13. Ogasawara, K., Yamada, K., Christeller, J. T., Kondo, M., Hatsugai, N., Hara-Nishimura, I. \& Nishimura, M. (2009). Constitutive and inducible ER bodies of Arabidopsis thaliana accumulate distinct $\beta$-glucosidases. Plant Cell Physiol., 50, No. 3. pp. 480-488. doi: https://doi.org/10.1093/pcp/pcp007

14. Matsushima, R., Fukao, Y., Nishimura, M. \& Hara-Nishimura, I. (2004). NAI1 gene that encodes a basic-helix-loop-helix-type putative transcription factor that regulates the formation of a novel ER-derived structure, the ER body. Plant Cell, 16, pp. 1536-1549. doi: https://doi.org/10.1105/tpc.021154

15. Sherameti, I., Venus, Y., Drzewiecki, C., Tripathi, S., Dan, V. M., Nitz, I., Varma, A., Grundler, F. M. \& Oelmüller, R. (2008). PYK10, a $\beta$-glucosidase located in the endoplasmatic reticulum, is crucial for the beneficial interaction between Arabidopsis thaliana and the endophytic fungus Piriformospora indica. Plant J., 54, pp. 428-439. doi: https://doi.org/10.1111/j.1365-313X.2008.03424.x

Received 28.02.2019

\section{С.Н. Романчук}

Институт ботаники им. Н.Г. Холодного НАН Украины, Киев

E-mail: rrsm@ukr.net ВЛИЯНИЕ Х-ОБЛУЧЕНИЯ НА ЭКСПРЕССИЮ ГЕНА $\beta$-ГЛЮКОЗИДАЗЫ
PYК 10 В ПРОРОСТКАХ ARABIDOPSIS THALIANA (L.) HEYNH.

Впервые исследована экспрессия гена $\beta$-глюкозидазы $P Y K ~ 10$ в проростках A. thaliana при действии X-облучения в дозах 0,5, 1, 2, 4, 6, 8, 10 и 12 Гр. Установлено, что при Х-облучении увеличение количества ЭРтелец и повышение активности $\beta$-глюкозидазы происходит за счет высокой экспрессии гена РYК 10. Впервые показана роль ЭР-телец, которые содержат $\beta$-глюкозидазу (PYК 10), в адаптации проростков A. thaliana на действие Х-облучения. Повышение экспрессии гена PYK 10 при этих условиях является частью внутренней программы защиты на воздействие внешних факторов.

Ключевые слова: ген РҮК 10, $\beta$-глюкозидаза, ЭР-тельца, X-облучение, Arabidopsis thaliana.

\section{S.M. Romanchuk}

M.G. Kholodny Institute of Botany of the NAS of Ukraine, Kiev

E-mail: rrsm@ukr.net

\section{THE EFFECT OF X-IRRADIATION ON $\beta$-GLUCOSIDASE PYK 10 GENE EXPRESSION IN ARABIDOPSIS THALIANA (L.) HEYNH. SEEDLINGS}

We have firstly investigated the expression of $\beta$-glucosidase $P Y K 10$ gene in A.thaliana seedlings under X-radiation doses of $0.5,1,2,4,6,8,10$, and 12 Gy. An increase in the number of ER-bodies and the $\beta$-glucosidase activity correlates with the enhancement of the PYK 10 expression. The increased PYK 10 expression in A. thaliana seedlings under $\mathrm{X}$-radiation is a part of the internal program of plant protection against the action of environmental factors. ER-bodies containing $\beta$-glucosidase may be one of the main components of a plant protection system from the influence of $\mathrm{X}$-radiation.

Keywords: gene PYK 10, $\beta$-glucosidase, ER-bodies, X-radiation, Arabidopsis thaliana. 